\title{
Executive Compensation, Executive Character, Audit Committee, and Audit Quality on Tax Avoidance
}

\author{
Kenny Ardillah" ${ }^{1 *}$, Agus Prasetyo C. ${ }^{2}$ \\ ${ }^{1}$ Institut Teknologi dan Bisnis Kalbis; ${ }^{2}$ Universitas Matana \\ 1/20617@lecturer.kalbis.ac.id; ²agus.prasetyo@matanauniversity.ac.id \\ ${ }^{*} P$ enulis korespondensi
}

\begin{abstract}
Tax avoidance turns into become most part satisfactory tax assessment practice, despite the fact that the practice isn't in opposition to the law that can't be acknowledged, should be forestalled, and gone against. This study expect to inform the impact of executive compensation, executive character, audit committee and audit quality on tax avoidance of mining companies listed on the Indonesia Stock Exchange. The sample selection method in this study uses purposive sampling. The sample of this study is mining companies listed on the Indonesia Stock Exchange. The data analysis technique used in this study is multiple linear regression. The results of this study proved that executive character has positive effect on tax avoidance and executive compensation, audit committee, and audit quality have no effect on tax avoidance. This research is required to be the reason for decision making by the management to not to rehearse tax avoidance and make thought for investor to not settle on speculation choices dependently on the evaluation of corporate governance perspectives that don't influence the organization in carrying out tax avoidance practice.
\end{abstract}

Keywords: tax avoidance, executive compensation, executive character, audit committee, audit quality

\begin{abstract}
Abstrak
Penghindaran pajak menjadi praktik penilaian pajak yang paling memuaskan, meskipun faktanya praktik tersebut tidak bertentangan dengan undang-undang, tidak dapat diakui, dan harus dicegah dan dilawan. Penelitian ini diharapkan dapat menginformasikan pengaruh kompensasi eksekutif, karakter eksekutif, komite audit dan kualitas audit terhadap penghindaran pajak pada perusahaan pertambangan yang terdaftar di Bursa Efek Indonesia. Metode pemilihan sampel dalam penelitian ini menggunakan purposive sampling. Sampel penelitian ini adalah perusahaan pertambangan yang terdaftar di Bursa Efek Indonesia. Teknik analisis data yang digunakan dalam penelitian ini adalah regresi linier berganda. Hasil penelitian ini membuktikan bahwa karakter eksekutif berpengaruh positif terhadap penghindaran pajak dan kompensasi eksekutif, komite audit, dan kualitas audit tidak berpengaruh terhadap penghindaran pajak. Penelitian ini diperlukan sebagai dasar pengambilan keputusan oleh manajemen untuk tidak melakukan penghindaran pajak dan menjadi dasar pemikiran investor untuk tidak mengambil keputusan spekulasi berdasarkan pada evaluasi perspektif corporate governance yang tidak mempengaruhi organisasi dalam menjalankan praktik penghindaran pajak.
\end{abstract}

Kata Kunci: penghindaran pajak, kompensasi eksekutif, karakter eksekutif, komite audit, kualitas audit 


\section{INTRODUCTION}

\section{Background}

Taxes are the biggest wellspring of state income, which in the designation of incomes is given to further develop training and individuals' government assistance, foundation improvement to help monetary development, increment strength and security, just as provincial turn of events. Funds acquired from taxes are additionally utilized for financing to make a feeling that all is well with the world for the local area, finance public products and pay off state obligations abroad. Not with-standing the spending capacity, taxes additionally have the capacity of reallocation of payment from individuals with higher financial capacities to individuals with lower monetary capacities (Meilia and Adnan, 2017).

This actually makes as many people as possible to avoid paying taxes because this is natural considering the tax system in Indonesia adheres to self-assessment, so that taxpayer compliance is one of the concerns of tax officials in carrying out their duties in the field of taxation (Marselawati, et al, 2018). The percentage of state revenue through taxes in Indonesia, which is very dominant compared to other sources of income, has forced the government to issue various policies in regulating aspects of taxation in Indonesia. The tax policy made by the government is used as a benchmark in making tax payments. Even though there is a law that regulates the taxation aspect, it is possible that there are loopholes for companies to commit fraud, such as tax avoidance practices. This causes the acquisition of state revenue sources not to run as it should. Various ways of evasion are carried out by taxpayers from the simplest to the most complex with the aim of minimizing the tax burden that should be paid to the state (Amalia and Ferdiansyah, 2019).

Realization of tax revenue in Indonesia throughout 2019 reached Rp. 1,332.1 trillion, grew 1.4\% compared to 2018. This total tax revenue has only reached around 84.4 percent of the 2019 State Budget (APBN) target of Rp. 1,577.6 trillion. Tax revenue for non-oil and gas Income Tax (PPh) in 2019 was recorded at Rp. 711.2 trillion or 85.9 percent of the target of Rp. 828.3 trillion and non-oil and gas of income tax revenues grew by 3.8 percent, lower in 2019 when compared to 14.9 percent growth in 2018. The low realization of tax revenues was due to the impact of declining revenues from the manufacturing and commodity industries. sectors and a volatile global economy. In addition, taxpayer compliance in 2019 is also a problem that can have an impact on tax revenue because taxpayer compliance does not reach the target set by the government of $80 \%$ with the realization of the number of taxpayers submitting SPT as many as 13.37 million. people or only $72.9 \%$ of the total taxpayers who are required to submit SPT.

Tax evasion is a generally accepted practice of taxation, although this practice, although not against the law, is unacceptable and should be prevented and opposed. Tax avoidance is one form of strategy that can be used by company management to make savings on the company's burden through efforts to minimize the payment of tax costs to be paid to the state which in turn can increase the company's net profit (Amri, 2017). This tax avoidance can be said to be a complicated and unique problem because in the economic aspect it is allowed in accounting practices, but is not desired by tax officials 
to be applied in corporate financial reporting. Nonetheless, the way that tax avoidance is done by misusing provisos in the tax law which in a real sense doesn't abuse the tax law makes the issue of tax avoidance to be a ceaseless issue (Wijaya, 2014).

The mining industry is one of the most highlighted business sectors in Indonesia because of the rampant tax evasion by companies operating in this business sector. During 2014-2018, the coal and lignite mining industry contributed an average of $2.3 \%$ of gross domestic product (GDP) per year or equivalent to Rp235 trillion. Coal is the subsequent supporter of assessment income from the extractive area after oil, gas and geothermal. The size of the monetary worth created by the coal mining industry isn't relative to the insignificant commitment of tax income to the state. From the capacity of coal production that focus in Indonesia which exceed 485 million tons, it just covers the coal production target that sourced from 8 organizations that have announced tax proportion contributed by the mineral and coal mining industry in 2016 is relatively small percentage with amount of $3.9 \%$, while the overall tax proportion to the state by the mineral and coal mining industry in 2016 only make contribution of $10.4 \%$.

Tax avoidance is related to setting an event in minimizing or eliminating the tax burden by taking into account whether there is a tax impact caused. Subsequently, tax avoidance isn't an infringement of expense laws or morally it's anything but thought to be inappropriate to lessen, keep away from, limit or reduce the taxation rate in manners that are permitted by charge laws (Zain, 2005:49). Tax evasion actions taken by companies are intended to take advantage of legal weaknesses, but do not violate applicable laws. Tax avoidance is done not by breaking the law, but by taking advantage by reducing tax obligations (Butje and Tjondro, 2014).

Agency theory is a part of game hypothesis that reviews the plan of agreements to inspire sane agents to follow up for the main principal when the agent's advantages struggle with the principals. Contrasts in light of a legitimate that concerned for agents and principals to prompt organization clashes, this contention happens in light of the chance of agents to do not act as the standard of interest by principals (Scott, 2015). The organizations face agency issues that were brought by information asymmetry between the board (agents) and stockholders (principals) and different issues if agencies (agents) use organization assets for individual benefit (Jensen and Meckling, 1976). Corporate governance is a continuation of the agency theory idea. Corporate governance assumes a part in dynamic decision making, remembering for terms of satisfying tax commitments, and arranging relies upon the elements of corporate governance (Friese, et.al, 2006). Corporate governance portrays the connection between various internal parties of the company to decide the way of the organization's performance. Organizations with great governance have a more significant level of tax avoidance. The quality of corporate governance assumes a significant part in deciding the affectability of tax incomes to make changes in tax rates (Marselawati, et.al, 2018).

One of the endeavors to lessen tax avoidance by organizations is executive compensation. Executive compensation is regularly seen as an instrument to adjust managerial interests 
(specialists) with stockholders (Banghoj, et. al, 2010). Tax directors and tax consultants can be directly involved in making tax avoidance decisions in a company. Corporate executives can influence corporate tax avoidance decisions because they can gain large financial benefits from tax avoidance policies carried out. The best effort in implementing efficiency related to corporate tax payments is to provide high compensation to executives (Apsari and Supadmi, 2018). Executives will feel benefited by receiving higher compensation, so that executives will improve company performance even better. One such performance is through the ability to increase the level of corporate tax avoidance (Hanafi, 2014).

Executive character has a close relationship with risk. Risk is an outcome or result that can happen because of a continuous interaction or future occasion and as whatever can influence the accomplishment of hierarchical objectives. Risk has a strong influence on the goals of a company because with the risk preference in carrying out policy strategies in a company, executives will tend to pay more attention to the impact that occurs or will occur on the decisions they make (Mayangsari, 2015). Executive character plays a role in reducing tax avoidance. Company leaders as decision and policy makers in the company certainly have different characters. A company leader can have a risk taker character which is a risk taker or a risk averse which is a risk averse. This is reflected in the decisions made by company leaders that affect the size of the company's risk (Budiman, 2012). The higher the risk of a company, the executives tend to be risk takers. Conversely, the lower the risk of a company, the executives tend to avoid risk (Dewi and Jati, 2014).

The audit committee is one of the company's organs in charge of overseeing the effectiveness of corporate governance. One of the duties of the audit committee is to review financial information issued by public companies to the public and or authorities, including financial statements, projections, and other reports related to financial information of public companies (Tjondro and Olivia, 2018). The presence of the audit committee is a lot of required in the organization to help the board of commissioners in expanding oversight over the administration of the organization, with the goal that it very well may be one of the endeavors to further develop board systems procedure (Nugraheni and Pratomo, 2018).

The information contained in the financial statements must go through an auditing process to ensure the reliability of the information. The audit process in a company requires an attitude of transparency, professionalism, accountability, and integrity. Transparency is an important factor in assessing audit quality because shareholders can find out information related to taxation which in this case knows the company's tendency to avoid taxes (Nugraheni and Pratomo, 2018). The audit process requires professionalism, accountability, and high integrity or transparency. Transparency is an important component of audit quality. To obtain high-quality audited financial reports, companies tend to use competent auditors from trusted public accountants such as the Public Accounting Firm's big four ( $Y$ and Niandari, 2018). Financial reports audited by the top four Public Accounting Firms will provide higher quality results than Public Accounting Firms that are not in the top four. The Public Accounting Firm's big four get a good reputation from the public because the audited financial statements have high credibility (Annisa and Kurniasih, 2012). 
Research on executive compensation and tax avoidance has been conducted several times. Several studies have stated that executive compensation has a negative effect on tax avoidance, namely Araujo (2019), Apsari and Supadmi (2018), Amri (2017), and Mayangsari (2015). On the other hand, the results which state that executive compensation has a positive effect on tax avoidance are obtained from Meilia and Adnan (2017). The results of other studies prove that executive compensation has no effect on tax avoidance obtained from Dewi and Sari (2015). The negative effect of executive character on tax avoidance is obtained from Novita's research (2016). Other results related to the positive influence of executive characteristics on tax avoidance were shown by Meilia and Adnan (2017) and Surachman (2015). The opposite result is shown in Amalia and Ferdiansyah's research (2019) which proves that executive characteristics have no effect on tax avoidance.

Research related to the effect of the audit committee on tax avoidance was obtained from Marselawati, et.al (2018) and Nurgaheni and Pratomo (2018) which proved that the audit committee had an effect on tax avoidance. The negative effect of the audit committee on tax avoidance is shown by Dewi and Jati (2014). The opposite result is shown by Jaeni, et.al (2018) and Dewi and Sari (2015) who prove that there is no effect of the audit committee on tax avoidance. The results of research related to audit quality that have a negative effect on tax avoidance were obtained from Tjondro and Olivia (2018), Kanagaretnam and Lobo (2016), and Dewi and Sari (2015). Dewi and Jati (2014) and Lestari and Nedya (2019) prove that audit quality has a positive effect on tax avoidance. Meanwhile, research by Amalia and Ferdiansyah (2019), Marselawati, et.al (2018), Nugraheni and Pratomo (2018), and Jaeni, et.al (2018) found that there was no effect of audit quality on tax evasion.

The independent variables used in this study are executive character and executive compensation and the dependent variable used in this study is tax avoidance which was replicated from research conducted by Meilia and Adnan (2017). The researcher added two independent variables, namely indicators of good corporate governance proxied by the audit committee and audit quality which was replicated from research conducted by Nugraheni and Pratomo (2018). The researcher changed the sample of companies to mining companies listed on the Indonesia Stock Exchange with a more recent period with a duration of 3 years from 2015-2017. This study expect to inform the impact of executive compensation, executive character, audit committee and audit quality on tax avoidance of mining companies listed on the Indonesia Stock Exchange.

Tax compliance hypothesis expresses that essentially there are no citizens who are willfully able to make pay tax charges. The individual will accomplish something on the off chance that he likewise profits by the activity. The executive as the functional head of the organization will actually want to make tax avoidance strategies just in the event that he likewise profits by the activity. Executive compensation is probably the most ideal approaches to execute corporate tax effectiveness. This is on the grounds that executive will feel profited by getting higher pay so it will further develop the organization's presentation stunningly better, one of which is through endeavors to expand the degree of corporate tax avoidance (Hanafi, 2014).

\section{$\mathrm{Ha}_{1}$ : Executive compensation has a positive effect on tax avoidance}


An executive basically has a different character. Differences in executive character will be reflected in the company's policy making, including tax avoidance practices. Executives have two different characters, namely risk takers and risk averse. Risk takers will use their courage to take more risks in tax avoidance practices, while risk avoiders will avoid taking those risks (Low, 2009). Tax avoidance by companies cannot be separated from the role of the executive in decision making. The executive must determine the number of alternative policy options and measure the magnitude of the risk that will be faced by certain characters. Every executive as a decision maker must have a certain character and play a role in tax avoidance practices (Dyreng, et. al, 2010). The executive character is seen from the company's risk and executives who dare to take big risks are expected to use their character to take tax avoidance actions (Amalia and Ferdiansyah, 2019).

\section{$\mathrm{Ha}_{2}$ : Executive character has a positive effect on tax avoidance.}

The audit committee is a committee that outlined by and proficiently responsible for board of commissioner in aiding the commitments and functions of board of commissioner with subject to the Decree of the Chairman of Bapepam and LK Number Kep. 643/BL/2012. One of the commitments of the audit committee is to review related information that had prepared by public organizations to the publics and authorities, including financial reports, projections, and various reports related to organizations' financial information. The audit committee views tax avoidance as a proficient point of view for organizations as taxpayers. The tax avoidance approach determines the company's decision to take tax avoidance measures as a measure of company dissatisfaction as a taxpayer towards the government and society (Tjondro and Olivia, 2018).

\section{$\mathrm{Ha}_{3}$ : The audit committee has a negative effect on tax avoidance}

The fundamental job of the auditor is to state a viewpoint on monetary announcing and revelation in regards to the reasonable show of all monetary data in all material regards dependent on the client company in accordance with generally accepted accounting principles. The measure of annual income tax expense paid by the organization can arrive at half of the organization's net income, so the auditor should consider the existence of corporate taxes in financial reporting. Auditors need to assess the legitimacy of the organization's accumulated tax payables and the organization's unforeseen tax liabilities on the balance sheet, tax expense on the income statement, and disclosures in the notes to the financial statements to give the public sensible confirmation about the company's divulgence and consistence order of records in financial reporting (Barrett, 2004).

The existence of material information about tax transactions that companies tend to hide in financial reporting disclosures makes auditors have to assess the company's involvement in tax transactions that have material values that have the potential to be misused by the company and found by the tax authorities. The auditor, if necessary, may require the client company to fairly present tax-related accounts in financial reporting by recording reserves or adjustments for unrecognized tax benefits by the company that 
increase the company's reported tax burden and reduce the financial reporting benefits of tax avoidance. company. The assurance that bookkeeping and taxable income are properly reported by the company in financial reporting can make the auditor indirectly reduce the ability and incentive of the company to do tax avoidance because large differences in the amount of tax can be a potential danger to the auditor and increase the likelihood of being detected by the auditor (Hanlon, 2005).

\section{$\mathrm{Ha}_{4}$ : Audit quality has a negative effect on tax avoidance}

\section{METHOD}

The population in this study are all mining companies listed on the Indonesia Stock Exchange. The sample in this study are mining companies listed on the Indonesia Stock Exchange for the 2016-2018 period that meet certain criteria. The reason the researcher chose mining companies as the research sample is because most small, medium and largescale taxpayers holders of mineral and coal mining business permits do not report their tax obligations and there are some general cases of mining companies in Indonesia that carry out tax avoidance practice such as those carried out by PT Adaro Energy Tbk in 2019 with allegations of tax evasion of USD 14 million per year since 2009. The researcher use purposive sampling as sample selection method in this research which turned into 41 companies with an aggregate of 35 research data acquired in the 2016-2018 period.

Table 1 Result of Sample Selection Procedure

\begin{tabular}{clcc}
\hline No. & \multicolumn{1}{c}{ Criteria Description } & $\begin{array}{c}\text { Amounts of } \\
\text { Companies }\end{array}$ & $\begin{array}{c}\text { Amount } \\
\text { of Data }\end{array}$ \\
\hline 1. & $\begin{array}{l}\text { Mining organization recorded on the Indonesia Stock Exchange } \\
\text { that distributes yearly financial statement and annual reports each } \\
\text { year straight from 2016-2018. }\end{array}$ & 41 & 123 \\
2. $\quad \begin{array}{l}\text { Mining companies that earn positive profit before tax and profit } \\
\text { after tax in a row from 2016-2018. }\end{array}$ & $(21)$ & $(63)$ \\
3. $\quad$ Mining companies that has all the data needed for research. & $(3)$ & $(16)$ \\
4. $\quad$ Mining companies that obtain an ETR value of more than 1. & & 35 \\
\hline
\end{tabular}

Source: Processed data

Tax avoidance is one of the expense management strategies utilized by organizations that doesn't struggle with tax laws since it's anything but a legitimate practice by misusing escape clauses in tax laws that influence the state revenue that derived from tax income (Dewi and Jati, 2014). The measurement of tax avoidance in this study uses the Cash Effective Tax Rates (Cash ETR) proxy. Cash ETR is the measurement of tax payment made by the organization from cash payment that results organization's net profit (Eksandy, 2017). Cash Effective Tax Rates (Cash ETR) is cash given for tax expenditure that has been divided by income before tax (Dyreng, et. al, 2008). The higher the rate level of CETR that 
is near the corporate tax rate, the lower the degree of tax avoidance by the organization. Then again, the lower the level of the CETR rate from the corporate annual income tax, the higher the degree of tax avoidance that can be deciphered by the organization (Tebiono and Sukadana, 2019). The scale used in measuring tax avoidance is the ratio scale. The formula for calculating tax avoidance is as follows.

$$
\text { Cash ETR }=\frac{\text { Cash Tax Paid }}{\text { Pretax Income }}
$$

Executive compensation is defined as the total compensation received by directors and commissioners. The measurement of executive compensation uses the natural logarithm of compensation to overcome the heterogeneity problem (Banghoj, et.al, 2010). The scale used in measuring executive compensation is a ratio scale. The formula for calculating executive compensation using the natural logarithm is as follows.

\section{Executive Compensation $=\mathrm{LN}$ (Total Executive Compensation)}

Executive character can be resolved dependently on risk of an organization. Organization's risk can be estimated by the standard deviation of EBITDA (income before interest, expenses, depreciation, and amortization) divided by the organization's total asset (Paligorova, 2010). The size of the company's risk reflects whether the company's executives are included in the risk taking or risk averse category. The greater the company's risk, the company's executives have risk-taking characteristics. Conversely, the smaller the company's risk indicates that the company's executives have risk averse characteristics. If the company's risk value is above average, it means that the executive is a risk taker (Meilia and Adnan, 2017). The scale used in measuring executive character is a ratio scale. The measurement of executive character is described in the following formula.

\section{Executive character $=$ Standard deviation of EBITDA/Total assets.}

The audit committee is a committee that works expertly and autonomously which is helped by the board of commissioners in doing the administrative duty of the financial reporting process, hazarding the executives, audit review execution, and the execution of corporate governance in the organization. The measurement of audit committee is determined by the amount of member of audit committee within the company (Nugraheni and Pratomo, 2018). The scale used in measuring the audit committee is a nominal scale.

Audit quality is an auditor's consideration of the company's ability to maintain its viability must be based on the assessment of a qualified auditor. Measurement of audit quality uses a dummy variable determined by the four main KAP services used by the company. If a company uses the services of the top four KAPs in auditing financial statements, it will be given a score of 1 , while companies that use services other than the top four KAPs are given a score of 0 (Nugraheni and Pratomo, 2018). The scale used in measuring audit quality is the nominal scale. 


\section{RESULTS AND DISCUSSION}

\section{Descriptive statistics}

Tax avoidance has a minimum value of 0,0845 and a maximum value of 0,8056 . The minimum value of tax avoidance of 0,0845 comes from the value of the Cash Effective Tax Rate at PT Dian Swastastika Sentosa Tbk. in 2016. The maximum tax avoidance value of 0,8056 comes from the cash Effective Tax Rate at PT Bayan Resources Tbk in 2018. The average value of tax avoidance is 0,3522 which indicates the low cash paid for tax expense from profit before tax Companies that engage in tax avoidance practices are unavoidable by the key management of mining companies listed on the Indonesia Stock Exchange. The value of the standard deviation of tax avoidance is 0,212 , where the value of the standard deviation of tax avoidance is smaller than the average value. This shows that tax avoidance has data that does not vary.

Executive compensation has a minimum value of 12,6480 and a maximum value of 17,0473 . The minimum annual executive compensation value is $\$ 311,170$ at PT Surya Esa Perkasa Tbk. in 2018. The maximum annual executive compensation amount is $\$ 25,325,000$ at PT Adaro Energy Tbk. in 2018. The average value of the natural logarithm of executive compensation is 14,6247 or $\$ 4,421,540$ which indicates a sizeable amount of annual executive compensation in the form of salaries, benefits, and incentives obtained by the key management of mining companies listed on the Indonesia Stock Exchange. Stock Exchange. The standard deviation of executive compensation is 1.1318, where the standard deviation of executive compensation is smaller than the average value. This shows that executive compensation has data that does not vary.

The executive character has a minimum score of 0,0154 at PT Surya Esa Perkasa Tbk in 2017. The maximum value of the executive character is 17,0473 at PT Resources Alam Indonesia in 2016. The executive character has an average value of 0.2544 , which means that the executive of a registered mining company in Indonesia the Stock Exchange on average still has a risk averse character by tending to choose a lower risk in making decisions. The standard deviation of the executive character is 0,1540 , where the standard deviation of the executive character is smaller than the average value. This shows that the executive character has data that does not vary.

The measure of audit committee inside mining organizations has a base individuals from 3 and most extreme individual from 4 . The audit committee has a normal worth of 3 individuals. There are 35 examples of mining organization information recorded on the Indonesia Stock Exchange utilized in this research with a level of $100 \%$. Every one of the mining organization information recorded on the Indonesia Stock Exchange have met the minimum base number of audit committee individuals with three individuals. There were 2 examples of mining organizations recorded on the Indonesia Stock Exchange had met in excess of three audit committee individuals with a level of 5,7\% which had namely PT Tambang Batubara Bukit Asam Tbk and PT Indo Tambangraya Megah Tbk. These outcomes demonstrate that practically all mining organizations recorded on the Indonesia Stock Exchange as the sample of this research have consented to the 
arrangements given by the 0JK, in particular POJK No. 55/POJK.04/2015 which requires the quantity of individuals from audit committee members to meet the minimum necessities of three individuals who came from independent commissioners and parties from outside of the organization.

There are 36 mining organization that recorded on the Indonesia Stock Exchange utilized in this research with a level of $100 \%$. There are 12 mining organizations recorded on the Indonesia Stock Exchange whose financial reports are inspected by a Public Accounting Firm that are excluded from the best four accounting public firms in Indonesia with a level of 33,3\%. The excess of 24 mining organization that recorded on the Indonesia Stock Exchange do the audit process of their financial reporting by utilizing Public Accounting Firm which is remembered for the main big four of accounting public firms in Indonesia with a level of 5,6\%. These results indicate that most of the mining companies listed on the Indonesia Stock Exchange pay attention to the quality of their financial reporting audits by using Public Accounting Firms which are included in the top four public accountant firms ranking.

\section{Classic Assumption Test}

The author used classic assumption test such as normality test, multicollinearity test, heteroscedasticity test, and autocorrelation test before do hypothesis tests with the result as follows.

Table 2 Classic Assumption Test Result

\begin{tabular}{|c|c|c|c|}
\hline $\begin{array}{c}\text { Classic } \\
\text { Assumption Test }\end{array}$ & Test Tools & Variables & $\begin{array}{l}\text { Value/Sig. } \\
(2 \text { tailed })\end{array}$ \\
\hline Normality Test & Kolmogorov-Smirnov & Residual & Sig. $(2$ tailed $)=0,051$ \\
\hline \multirow[t]{4}{*}{ Multicollinearity Test } & VIF and Tolerance & Executive compensation & $\begin{array}{l}\text { VIF }=1,239 \\
\text { Tolerance }=0,807\end{array}$ \\
\hline & & Executive character & $\begin{array}{l}\mathrm{VIF}=1,026 \\
\text { Tolerance }=0,975\end{array}$ \\
\hline & & Audit committee & $\begin{array}{l}\text { VIF }=1,180 \\
\text { Tolerance }=0,848\end{array}$ \\
\hline & & Audit quality & $\begin{array}{l}\text { VIF }=1,381 \\
\text { Tolerance }=0,768\end{array}$ \\
\hline \multirow[t]{4}{*}{ Heteroscedasticity Test } & Glejser Test & Executive compensation & Sig. $(2$ tailed $)=0,388$ \\
\hline & & Executive character & Sig. $(2$ tailed $)=0,511$ \\
\hline & & Audit committee & Sig. $(2$ tailed $)=0,710$ \\
\hline & & Audit quality & Sig. $(2$ tailed $)=0,273$ \\
\hline Autocorrelation Test & Breusch-Godfrey Test & Residual & Asymp Sig. $(2$ tailed $)=0,398$ \\
\hline
\end{tabular}

Source: Processed data

The results of the normality test show the asymp.sig value. (2-tailed) obtained is 0,051 which means the value of asymp.sig. (2-tailed) above 0,05. This means that Ho 
cannot be rejected which shows that the data on executive compensation, executive character, audit committee, audit quality, and tax avoidance are normally distributed. The results of the multicollinearity test show that executive compensation, executive character, audit committee, and audit quality have a tolerance value above 0,1 and a VIF value below 10. This indicates that executive compensation, executive character, audit committee, and audit quality do not experience multicollinearity problem. This means that the regression model is free from multicollinearity problems and can be used in research.

The results of the heteroscedasticity test show that executive compensation, executive character, audit committee, and audit quality have sig. values (2-tailed) above 0,05. These results indicate that executive compensation, executive character, audit committee, and audit quality do not experience heteroscedasticity problems and can be used in research. The results of the autocorrelation test in table 4.8 show that the residual data has a sig. value of 0,398 which means the asymp sig. value (2-tailed) was obtained above 0,05. This means that Ho cannot be rejected which indicates that there is no autocorrelation between executive compensation, executive character, audit committee, and audit quality with absolute residual value. These results indicate that the regression model is free from autocorrelation problems and can be used in research.

\section{Coefficient of Determination Test}

In table 3 , the author used coefficient of determination to explain the variation of independent variables to predict dependent variable.

Table 3 Coefficient of Determination Test Result

\begin{tabular}{cc}
\hline Model & Adjusted R square \\
\hline 1 & 0,099 \\
\hline
\end{tabular}

Source: Processed data

The R-square value obtained in this study is 0,099 . This implies that $9,9 \%$ of the variety in tax avoidance can be clarified by executive compensation, executive character, audit committee, and audit quality. The leftover $90,1 \%$ of the variety in tax avoidance is clarified by different elements that are excluded from the relapse model.

\section{F-Test}

In table 4 , the author used f-test to examine the fit model of this research.

Tabel 4 F-Test Result

\begin{tabular}{cc}
\hline Model & Sig. (2-tailed) \\
\hline 1 & 0,030 \\
\hline
\end{tabular}

Source: Processed data 
The outcome with sig value. (2-tailed) acquired from the f test of 0,030 which implies the worth of sig. (2-tailed) is below 0,05 . This result means the examination model is fit and appropriate for use in research.

\section{T-test}

The consequences of the t-test in this examination are introduced in table 5 with the accompanying test outcomes.

Table 5 T-test Result

\begin{tabular}{lcc}
\hline \multicolumn{1}{c}{ Variable } & Coefficient & Sig. (2 tailed) \\
\hline Constant & 0,723 & \\
Executive Compensation & $-0,216$ & 0,859 \\
Executive Character & 0,314 & 0,004 \\
Audit Committee & $-0,080$ & 0,617 \\
Audit Quality & 0,066 & 0,478 \\
\hline
\end{tabular}

Source: Processed data

Based on the result in table 5, the regression model utilized in this research as per the following.

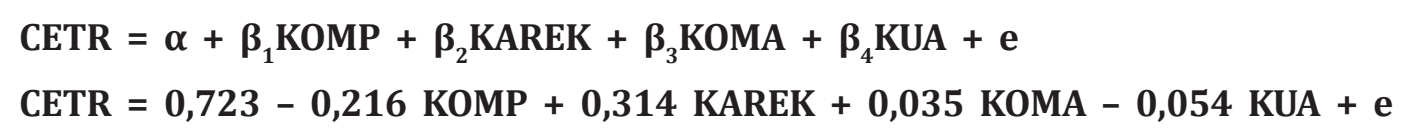

There is a partial impact of the independent variables on the dependent variable with the accompanying result as follows.

1. Executive compensation has a significance value of 0,859 , which means a significance value of more than 0.05 , which means $\mathrm{Ha}_{1}$ is rejected. This shows that executive compensation has no effect on tax avoidance.

2. Executive character has a significance value of 0,004 , which means a significance value of more than 0.05 , which means $\mathrm{Ha}_{2}$ is accepted. This shows that the executive character has effect on tax avoidance.

3. The audit committee has a significance value of 0,617 , which means a significance value of more than 0.05 , which means $\mathrm{Ha}_{3}$ is rejected. This shows that the audit committee has no effect on tax avoidance.

4. Audit quality has a significance value of 0,478 , which means a significance value of more than 0.05 , which means $\mathrm{Ha}_{4}$ is rejected. This shows that audit quality has no effect on tax avoidance. 


\section{Effect of Executive Compensation on Tax Avoidance}

The coefficient of executive compensation on tax avoidance is negative at $-0,216$, which means the greater the amount of executive compensation paid by the company, the practice of tax avoidance decreases. Executive compensation on tax evasion has a sig value. (2-tailed) of 0,859 which means greater than 0.05 . This shows that $\mathrm{Ha}_{1}$ is rejected, which means the executive compensation has no effect on tax avoidance. The results of this study are consistent with Dewi and Sari (2015) who state executive compensation has no effect on tax avoidance. The results of this study are inconsistent with Araujo (2019), Apsari and Supadmi (2018), Amri (2017), Meilia and Adnan (2017), and Mayangsari (2015) which state executive compensation has an effect on tax avoidance.

Executive compensation does not affect tax avoidance because the size of executive compensation does not affect key management in making decisions to do tax avoidance. Executive compensation received by key management in open-pit mining companies in Indonesia uses the same form of compensation in the form of salaries, incentives, allowances and annual bonuses with the amounts of executive incentives issued by companies that are quite high from all business sectors of public companies in Indonesia. The non-share-based compensation system in public companies in Indonesia also creates a lack of motivation for corporate executives to practice tax avoidance.

\section{Effect of Executive Character on Tax Avoidance}

The coefficient of executive character on tax avoidance is positive at 0,314, which means that an increase in executive character makes tax avoidance practices increase. The executive character of tax avoidance has a sig value. (2-tailed) of 0,004 which means it is lower than 0.05 . This shows that $\mathrm{Ha}_{2}$ is accepted, which means that the executive character has positive effect on tax avoidance. The results of this study doesn't support the research of Amalia and Ferdiansyah (2019) which proves that the executive character has no effect on tax avoidance. The results of this study are consistent with Meilia and Adnan (2017), Novita (2016), and Surachman (2015) which prove the influence of executive character on tax avoidance.

The executive character has positive effect on tax avoidance because shareholders still have a stronger influence in the company compared to executives in making decisions in the company, including in carrying out tax avoidance policies. The executive is required by the shareholders to carry out the wishes of the shareholders, either in doing or not carrying out tax avoidance policies. As a result, even though executives have a risk-averse character, executives are required to dare to take high risks to fulfill the wishes of shareholders. These results support the agency and stewardship theory which states that executives as stewards are motivated to act according to the wishes of the principal and have the behavior to be invited to cooperate in the organization, have collective or group behavior with high utility compared to individually, and are always willing to serve the principal. 


\section{Effect of the Audit Committee on Tax Avoidance}

The coefficient of the audit committee on tax avoidance is negative at $-0,080$, which means that the presence of an audit committee in the company can decrease tax avoidance practices. Accounting conservatism on tax avoidance has a sig value. (2-tailed) of 0,617 which means greater than 0.05 . This shows that $\mathrm{Ha}_{3}$ is rejected, which means that the audit committee has no influence on tax avoidance. The results of this study support Jaeni, et.al (2018) which proves that there is no effect of the audit committee on tax avoidance. The results of this study are inconsistent with Marselawati, et.al (2018), Nurgaheni and Pratomo (2018), and Dewi and Jati (2014) which prove that the audit committee has an effect on tax avoidance.

The audit committee has no effect on tax avoidance because of the presence of audit committee that is approved to do oversight and assessment of the organization's functional performance and the execution of corporate governance that doesn't have a relationship with tax avoidance practices that happen in the organization. The huge number of audit committee in the organization doesn't ensure that the audit committee can forestall tax avoidance by the organization. This is built up by the commitment for public organizations to consent to the arrangements of POJK No. 55/POJK.04/2015 which requires the quantity of individuals from the audit committee possessed by the organization to meet the base necessity of three individuals who can emerge out from independent commissioners and parties from outside the organization which in the end makes the presence of audit committee just a custom prerequisite for the organization. The result of tabulation from audit committee information will in general to be homogeneous or not fluctuated so it is hard to have the option to make exact estimations in demonstrating the impact of the audit committee on tax avoidance.

\section{The Effect of Audit Quality on Tax Avoidance}

The coefficient of audit quality on tax avoidance is positive at 0,066, which means that audit quality in the company can increase tax avoidance practices. The audit quality of tax avoidance has a sig value. (2-tailed) of 0,478 which means greater than 0.05 . This shows that $\mathrm{Ha}_{4}$ is rejected, which means audit quality has no effect on tax avoidance. The results of this study support Amalia and Ferdiansyah (2019), Marselawati, et.al (2018), Nugraheni and Pratomo (2018), and Jaeni, et.al (2018) who found that there was no effect of audit quality on tax avoidance. The results of this study do not support Lestari and Nedya (2019), Tjondro and Olivia (2018), Kanagaretnam and Lobo (2016), and Dewi and Jati (2014) which prove that audit quality affects tax avoidance.

The results of testing the fourth hypothesis indicate that there is no effect of audit quality on tax avoidance. These results indicate that there is no significant difference between the audit quality applied by public companies which in the process of auditing their financial reporting use the services of big four Public Accounting Firms and non-big four Public Accounting Firms. These results also indicate that in the process of auditing financial reporting using the big four Public Accounting Firms or the non-big four Public 
Accounting Firms, both of them carry out the auditing process and provide the same auditing results. Public Accounting Firms, both big four and non-big four, are confirmed to have a good reputation in auditing the company's finances based on quality control standards on audit quality set by the Indonesian Public Accountant Professional Standards Board (DSAP IAPI) and regulations made by the Indonesian Public Accountants. The Indonesian Institute of Public Accountants (IAPI), so that it is ensured that in carrying out the audit it is in accordance with the rules that have been set.

\section{CONCLUSIONS}

The results of the first hypothesis test prove that $\mathrm{Ha}_{1}$ is rejected, which means that executive compensation has no effect on tax avoidance. Executive compensation does not affect tax avoidance because the size of executive compensation does not affect key management in making decisions to do tax avoidance. The results of the second hypothesis test prove that $\mathrm{Ha}_{2}$ is accepted, which means that the executive character has positive effect on tax avoidance because shareholders still have a stronger influence in the company compared to executives in making decisions in the company, including in carrying out tax avoidance policies, so executives must continue to comply shareholders' interests even though they have different characters. The results of the third hypothesis test prove that $\mathrm{Ha}_{3}$ is rejected, which means that the audit committee has no effect on tax avoidance. The audit committee has no effect on tax avoidance due to the existence of an audit committee that is authorized to carry out supervision and evaluation of the company's operational performance and the implementation of corporate governance does not have a close relationship with tax avoidance activities that occur in the company. The results of the fourth hypothesis test prove that $\mathrm{Ha}_{4}$ is rejected, which means audit quality has no effect on tax avoidance. Audit quality has no effect on tax avoidance because both in the process of auditing financial reporting using a big four Public Accounting Firm or a non-big four Public Accounting Firm, both of them carry out the audit process and provide the same auditing results.

This research result can be used by management as the basis for decision making by company management not to practice tax avoidance. For investors, this research is expected to be a basis for consideration for investors not to make investment decisions based on the assessment of corporate governance aspects that do not affect the company in carrying out tax avoidance practices such as executive compensation, executive character, audit committee, and audit quality. Future researchers are expected to add a longer research period of at least 5 years in order to provide better research results. Subsequent research can use companies with other business sectors besides the mining sector such as the manufacturing sector which is the company sector with the largest number of publicly listed companies in Indonesia which can represent the total population of companies listed on the Indonesia Stock Exchange. Subsequent research can add other independent variables that affect tax avoidance practices by companies such as financial condition, company characteristics, and other corporate governance indicators such as managerial ownership, independent commissioners, and independent audit committees. In addition, future research can use other tax avoidance measures such as Current ETR and Book Tax Difference. 


\section{REFERENCES}

Amalia, Diah dan Steven Ferdiansyah. 2019. Does Political Connection, Executive Character, and Audit Quality Affect The Tax Avoidance Practice ? Evidence in Indonesia. Sebelas Maret Business Review, Vol. 4, No. 2, pp. 93-101.

Amri, Muhtadin. 2017. Pengaruh Kompensasi Manajemen terhadap Penghindaran Pajak dengan Moderasi Diversifikasi Gender Direksi dan Preferensi Risiko Eksekutif Perusahaan di Indonesia. Jurnal Aset (Akuntansi Riset), Vol. 9, No. 1, pp. 1-14.

Annisa, N.A. dan L. Kurniasih. 2012. Pengaruh Corporate Governance terhadap Tax Avoidance. Jurnal Akuntansi dan Auditing, Vol. 8, No. 2, pp. 123-136.

Apsari, A.A.A.N.C. dan N.L. Supadmi. 2018. Pengaruh Kompensasi Eksekutif, Koneksi Politik, dan Capital Intensity pada Tax Avoidance. E-Jurnal Akuntansi Universitas Udayana, Vol. 25, No. 2, pp. 1481-1505.

Araujo, J.J.O. 2019. Tax Avoidance, CEO Compensation and Corporate Governace : The Brazilian Case, International Finance Conference XIX.

Banghoj, J., G. Gabrielsen, C. Petersen., dan T. Plenborg. 2010. Determinants of Executives Compensation in Privately Held Firms. Accounting and Finance, Vol. 50, pp. 481-510.

Barrett, M. J. 2004. Tax Services As A Trojan Horse In The Auditor Independence Provisions of Sarbanes-Oxley. Michigan State Law Review, pp. 463-504.

Budiman, Judi. 2012. Pengaruh Karakter Eksekutif Terhadap Penghindaran Pajak (Tax Avoidance). Jurnal Universitas Islam Sultan Agung.

Butje, S. dan Tjondro, E. 2014. Pengaruh Karakter Eksekutif dan Koneksi Politik Terhadap Tax Avoidance. Tax and Accounting Review, Vol. 4, pp. 1-9.

DeAngelo, L.E. 1981. Auditor Size and Audit Quality. Journal of Accounting and Economics, pp. 183-199.

Dewi, N. N., dan Jati, I. K. 2014. Pengaruh Karakteristik Eksekutif, Karakteristik Perusahaan, dan Dimensi Tata Kelola Perusahaan yang Baik Pada Tax Avoidance di Bursa Efek Indonesia. E-Jurnal Akuntansi Universitas Udayana, Vol. 6, No. 2, pp. 249-260.

Dewi, G. A. P dan M. M. R. Sari. 2015. Pengaruh Insentif Eksekutif, Corporate Risk dan Corporate Governance pada Tax Avoidance. E-Jurnal Akuntansi Universitas Udayana, Vol. 13, No. 1, pp. 50-67.

Dyreng, Scot D., H. Michelle, dan E.L. Maydew. 2010. The Effect of Executives on Corporate Tax Avoidance. The Accounting Review. Vol. 85(4), pp. 1163-1189.

Eksandy, A. 2017. Pengaruh Komisaris Independen, Komite Audit, dan Kualitas Audit Terhadap Penghindaran Pajak (Tax Avoidance). Competitive, Vol. 1, pp. 1-55.

Hanafi, Umi. 2014. Pengaruh Kompensasi Eksekutif, Kepemilikan Eksekutif dan Preferensi Risiko Eksekutif Terhadap Penghindaran Pajak Perusahaan. Diponegoro Journal of Accounting, Vol. 3, No. 2, pp. 1-11.

Hanlon. 2005. The Persistence and Pricing of Earnings, Accruals, and Cash Flows When Firms Have Large Book-Tax Differences. The Accounting Review, Vol. 80 (1), pp. 137-166. 
Indriantoro, Nur., dan Supomo, Bambang. 2013. Metodologi Penelitian Bisnis Untuk. Akuntansi \& Manajemen. Yogyakarta: BPFE.

Institut Akuntan Publik Indonesia. 2011. Standar Porfesional Akuntan Publik. Jakarta: Salemba Empat.

Jaeni, Jaeni, A. Badjuri, dan Z.R. Fadhila. 2018. Effect of Good Corporate Governance, Profitability, and Leverage on Tax Avoidance Behavior Before and After Tax Amnesxty (Empiritical Study on Manufacturing Company Listed in Indonesia Stock Exchange Period 2015-2016). Advances in Economics, Business, and Management Research, Vol. 86, pp. 149-154.

Kanagaretnam, Kiridaran dan G. Lobo. 2016. Does Auditor Quality Constrain Corporate Tax Avoidance ? Some International Evidence. Auditing A Journal Practice and Theory.

Kurniasih, T. dan Sari, M.M.R. 2013. Pengaruh Return On Assets, Leverage, Corporate Governance, Ukuran Perusahaan dan Kompensasi Rugi Fiskal pada Tax Avoidance. Buletin Studi Ekonomi, Vol. 1 (18), pp. 58-66.

Low, A. 2009. Managerial Risk Taking Behavior and Equity Based Compensation, Journal of Financial Economics, pp. 1-42.

Marselawati, Dina, K. H. Titisari, dan E. Masitoh. 2018. The Effect of Corporate Governance on Tax Avoidance (Empirical Study of The Consumer Goods Industry Companies Listed on Indonesia Stock Exchange Period 2013-2016). The $2^{\text {nd }}$ International Conference of Technology, Education, and Social Science 2018.

Mayangsari, Cindy. 2015. Pengaruh Kompensasi Eksekutif, Kepemilikan Saham Eksekutif, Preferensi Risiko Eksekutif, dan Leverage terhadap Penghindaran Pajak (Tax Avoidance). Jom FEKON, Vol. 2, pp.1-15.

Meilia, Putri dan Adnan. 2017. Pengaruh Financial Distress, Karakteristik Eksekutif, dan Kompensasi Eksekutif terhadap Tax Avoidance pada Perusahaan Jakarta Islamic Index. Jurnal Ilmiah Mahasiswa Ekonomi Akuntansi (JIMEKA), Vol. 2, No. 4, pp. 84-92.

Novita, Nova. 2016. Executive Characters, Gender, and Tax Avoidance: A Study on Manufacturing Companies in Indonesia. Advances in Economics, Business, and Management Research, Vol. 15, pp. 92-95.

Nugraheni, A.S. dan D. Pratomo. 2018. Pengaruh Komite Audit, Kualitas Audit, dan Ukuran Perusahaan terhadap Tax Avoidance (Studi pada Perusahaan Manufaktur Subsektor Otomotif yang Terdaftar di Bursa Efek Indonesia Tahun 2012-2016). E-Proceeding of Management, Vol. 5, No. 2, pp. 2227-2234.

Paligorova, T. 2010. Corporate Risk-Taking and Ownership Structure. Bank of Canada Working Paper, pp. 1-41.

Suandy, Erly. 2011. Perencanaan Pajak Edisi 5. Jakarta : Salemba Empat.

Sugiyono. 2015. Metode Penelitian Kombinasi (Mixed Methods) Edisi 7. Bandung : CV. Alfabeta.

Surachman, A.E. 2015. Influence of Executive Characteristic and Duality of Chief Executive Officer to Tax Avoidance. International Journal of Science and Research, Vol. 6, No. 10, pp. 1671-1677. 
Tebiono, J.N. dan I.B.N.Sukadana. 2019. Faktor-Faktor yang Mempengaruhi Tax Avoidance pada Perusahaan Manufaktur yang Terdaftar di BEI. Jurnal Bisnis dan Akuntansi, Vol. 21, No. 1a-2, pp. 121-130.

Tjondro, Elisa dan V. Olivia. 2018. Role of Audit Committee in Tax Avoidance of Family and Non Family Firms : Evidence From Indonesia. Journal of Economics and Business, Vol. 1, No. 3, pp. 368-380.

Wijaya, I. 2014. Mengenal Penghindaran Pajak Tax Avoidance. www.pajak.go.id.

Y, R. H., dan N. Niandari. 2018. Tax Avoidance Practice: Political Connection, Firm Characteristics, and Audit Quality Test at Banking Industrial in Indonesia. International Journal of Business Management and Economic Research (IJBMER), Vol. 9, pp. 1296-1303.

Zain, Mohammad. 2005. Manajemen Perpajakan. Jakarta : Salemba Empat. 